\title{
Distinct lake level lowstand in Lake Prespa (SE Europe) at the time of the 74 (75) ka Toba eruption
}

\author{
B. Wagner ${ }^{1}$, M. J. Leng ${ }^{2,3}$, T. Wilke ${ }^{4}$, A. Böhm ${ }^{1}$, K. Panagiotopoulos ${ }^{5}$, H. Vogel ${ }^{6}$, J. H. Lacey ${ }^{2}$, G. Zanchetta ${ }^{7}$, and \\ R. Sulpizio ${ }^{8,9}$ \\ ${ }^{1}$ Institute of Geology and Mineralogy, University of Cologne, Zülpicher Str. 49a, 50674 Cologne, Germany \\ ${ }^{2}$ Department of Geology, University of Leicester, Leicester, LE1 7RH, UK \\ ${ }^{3}$ NERC Isotope Geosciences Laboratory (NIGL), British Geological Survey, Keyworth, Nottingham, NG12 5GG, UK \\ ${ }^{4}$ Department of Animal Ecology \& Systematics, Justus Liebig University, Heinrich-Buff-Ring 26-32, \\ 35392 Giessen, Germany \\ ${ }^{5}$ Seminar of Geography and Education, University of Cologne, Gronewaldstraße 2, 50931 Cologne, Germany \\ ${ }^{6}$ Institute of Geological Sciences \& Oeschger Centre for Climate Change Research, University of Bern, Baltzerstrasse $1+3$, \\ 3012 Bern, Switzerland \\ ${ }^{7}$ Dipartimento di Scienze della Terra, University of Pisa, via S. Maria 53, 56126 Pisa, Italy \\ ${ }^{8}$ Dipartimento di Scienze della Terra e Geoambientali, University of Bari, via Orabona 4, 70125 Bari, Italy \\ ${ }^{9}$ IDPA-CNR, via Mario Bianco 9, Milan, Italy
}

Correspondence to: B. Wagner (wagnerb@uni-koeln.de)

Received: 27 May 2013 - Published in Clim. Past Discuss.: 19 June 2013

Revised: 13 January 2014 - Accepted: 21 January 2014 - Published: 6 February 2014

\begin{abstract}
The 74 (75) ka Toba eruption in Sumatra, Indonesia, is considered to be one of the largest volcanic events during the Quaternary. Tephra from the Toba eruption has been found in many terrestrial and marine sedimentary deposits, and acidity peaks related to the eruption have been used to synchronize ice core records from Greenland and Antarctica. Seismic profiles and sedimentological data from Lake Prespa on the Balkan Peninsula, SE Europe, indicate a lake level lowstand at $73.6 \pm 7.7 \mathrm{ka}$ based on ESR dating of shells. Tephrostratigraphy, radiocarbon dating and tuning of the total organic carbon content with the NGRIP isotope record, corroborate that the lake level lowstand was a short-term event superimposed on the general cooling trend at the end of MIS 5, most likely at the onset of the Greenland Stadial GS20. Acknowledging that tectonic events or karst processes could have triggered this lake level lowstand, the chronological correspondence between the lowstand and the Toba eruption is intriguing. Therefore a Toba-driven short-term shift to aridity in the Balkan region, leading to lake level changes and triggering spatial expansion events in one of the lake's most abundant benthic species, the carino mussel Dreissena presbensis, cannot be excluded.
\end{abstract}

\section{Introduction}

The Toba caldera complex in North Sumatra, Indonesia formed due to a number of volcanic eruptions, of which the most recent around $74 \mathrm{ka}$ is considered to be one of the largest to occur on Earth during the Quaternary (Chesner, 2012). The tephra products from this eruption can be found in many sedimentary sequences from the Arabian Sea in the west to the South China Sea in the east (e.g. Williams, 2012a and references therein). Though differing ages can be found in the literature, the most precise dating of the Toba eruption is thought to be achieved using Ar/Ar of the tephra, which indicates ages of $73.88 \pm 0.3$ (Storey et al., 2012) and $75.0 \pm 0.9 \mathrm{ka}$ (Mark et al., 2013). The impact of the Toba eruption on regional climatic and hydrological conditions, and on regional human dispersal and activity, are relatively well known (e.g. Blinkhorn et al., 2012; Jones, 2012; Petraglia et al., 2012). Some authors suggest that the Toba eruption was followed by a volcanic winter, i.e. a decade or two of drastic cooling (compiled in Williams, 2012a, b). On a regional scale, this could have affected plants and animals as well as human populations (e.g. Jones, 2012; Louys, 2012). 
The global impact of the Toba eruption is still under debate (Williams, 2012b). Acidity peaks, occurring at the transition from Greenland Interstadial 20 (GI-20) into Greenland Stadial 20 (GS-20) in the NGRIP ice core record from Greenland, and during a prominent isotope minimum between Antarctic Isotope Maxima (AIM) 20 and 19 in the EDML and EDC ice core records from Antarctica, are correlated with the Toba eruption (Svensson et al., 2013). However, it is difficult to explain sustained cold temperatures over more than a millennium as a result of the Toba event (Svensson et al., 2013). Climate models suggest both strong and longlasting cooling and devastating impacts on both ecosystems and humans (e.g. Ambrose, 1998; Robock et al., 2009), while others suggest the contrary, with only moderate changes in temperature in S and E Africa and on the Indian subcontinent, but with significant precipitation anomalies (Timmreck et al., 2012). The potential global climate impact of the Toba eruption could have also affected the dispersal of modern humans from Africa to Europe (Oppenheimer, 2012; Petraglia et al., 2012).

To gain a better understanding of the environmental impact of the Toba eruption, more records from distal sites are required. Here, we provide seismic and sedimentological data from Lake Prespa, which is situated in SE Europe between Albania, Macedonia, and Greece (Fig. 1) and is located on the pathway of human dispersal from Africa to Europe (Oppenheimer, 2012). Published data from Lake Prespa indicate that the sedimentary record is very sensitive to environmental change over the last $92 \mathrm{ka}$, which is partly due to a relatively small volume $\left(3.6 \mathrm{~km}^{3}\right)$, a large surface area $\left(254 \mathrm{~km}^{2}\right)$, and a mean water depth of only ca. $14 \mathrm{~m}$ (Wilke et al., 2010; Damaschke et al., 2013; Wagner et al., 2012; Leng et al., 2013; Panagiotopoulos et al., 2013b). However, none of the published studies have considered that the sedimentary record could indicate the impact of the 74 (75) ka Toba eruption.

\section{Data set and discussion}

The seismic and sedimentological data presented here from Lake Prespa have been previously published and discussed in more detail with respect to long-term environmental change (Wagner et al., 2010, 2012; Leng et al., 2013; Panagiotopoulos et al., 2013b). Radiocarbon dates, tephrostratigraphy, ESR dating and cross correlation with the NGRIP ice core indicate that the sediment core Co1215 spans the last ca. $92 \mathrm{ka}$ (Damaschke et al., 2013; Fig. 2). Total inorganic carbon (TIC) and total organic carbon (TOC) from the sediments were measured in $2 \mathrm{~cm}$ intervals, corresponding to a centennial resolution, and show both Glacial/Interglacial periods, as well as short-term climate events, including Heinrich and the 8.2 ka events (e.g. Wagner et al., 2010, 2012; Aufgebauer et al., 2012; Panagiotopoulos et al., 2013a; Fig. 2). The stable isotope data also show both long-term and short-term changes in the lake hydrology (Leng et al., 2013).

A distinct lithological horizon in the core occurs between 14.63 and $14.58 \mathrm{~m}$ depth, where whole shells and shell fragments of the carino mussel (probably Dreissena presbensis) were found (Fig. 2). This horizon most likely represents a distinct lake level lowstand, which is also indicated by an undulated reflector in the seismic data (see Wagner et al., 2012, Fig. 1) and by high $\delta^{18} \mathrm{O}$ from the shell fragments (see Leng et al., 2013, Fig. 2). Moreover, a peak in the TOC/N ratio and a conspicuous Poaceae peak (Fig. 2), which includes Phragmites sp. pollen grains, points to an expansion of the littoral zone and a decreasing lake surface area (Panagiotopoulos et al., 2013b). The pollen data also indicate that this short-term event occurred at the onset of a longer period defined by a maximum of non-arboreal pollen percentages. Tree cover within the catchment decreases between ca. 75 and $71 \mathrm{ka}$, likely corresponding to the Greenland Stadial 20 (GS-20), and implies colder and dryer conditions within the catchment (Panagiotopoulos et al., 2013b).

The ESR dates of the Dreissena shells and shell fragments from the Lake Prespa core provide a mean age for the deposition of the shell horizon and the reconstructed lake level lowstand of $73.6 \pm 7.7 \mathrm{ka}$ (Damaschke et al., 2013). Despite relatively large uncertainty, the mean age is supported by tephrostratigraphic markers above the shell horizon and by chronological tie points below and above the shell horizon (Damaschke et al., 2013). The chronological tie points were obtained by cross correlation of mainly TOC, which is known to be a very sensitive proxy of climatic change in the Lake Prespa sediments (Wagner et al., 2010), with the NGRIP ice core record (Fig. 2). A TOC maximum directly below the shell horizon, at $1472 \mathrm{~cm}$ depth, likely corresponds to the GI-20 between ca. 76 and 74 ka (Fig. 2; Wolff et al., 2010). The TOC peak above the shell horizon occurs at $1394 \mathrm{~cm}$ and likely corresponds to the GI-19 between ca. 72 and $70 \mathrm{ka}$ (Wolff et al., 2010). As there is no lithological or chronological evidence for a distinct change in sedimentation rate through core Co1215 (Fig. 2), if the ESR age of $73.6( \pm 7.7) \mathrm{ka}$ is reliable, then the deposition of the shells occurred at the onset of GS-20. We can exclude that the lake level lowstand is related to a long-term change from interglacial to glacial conditions at the Marine Isotope stage (MIS) 5 to MIS 4 boundary, such as indicated by the pollen data with cold and dry conditions prevailing between ca. 75 and $71 \mathrm{ka}$ (Panagiotopoulos et al., 2013b). The shell horizon is about $5 \mathrm{~cm}$ thick, which would correspond to a period of ca. $250 \mathrm{yr}$ based on an average sedimentation rate of ca. $0.02 \mathrm{~cm} \mathrm{yr}^{-1}$ throughout the core (core length $1780 \mathrm{~cm}$ and basal age of $92 \mathrm{ka}$ ). However, no shells were found in life position. Redistribution and reworking of shell fragments suggest a relatively high sedimentation rate and imply that the $5 \mathrm{~cm}$-thick horizon could represent a much shorter period, probably between a few days and a few decades. We can also exclude the possibility that the lowstand was triggered 


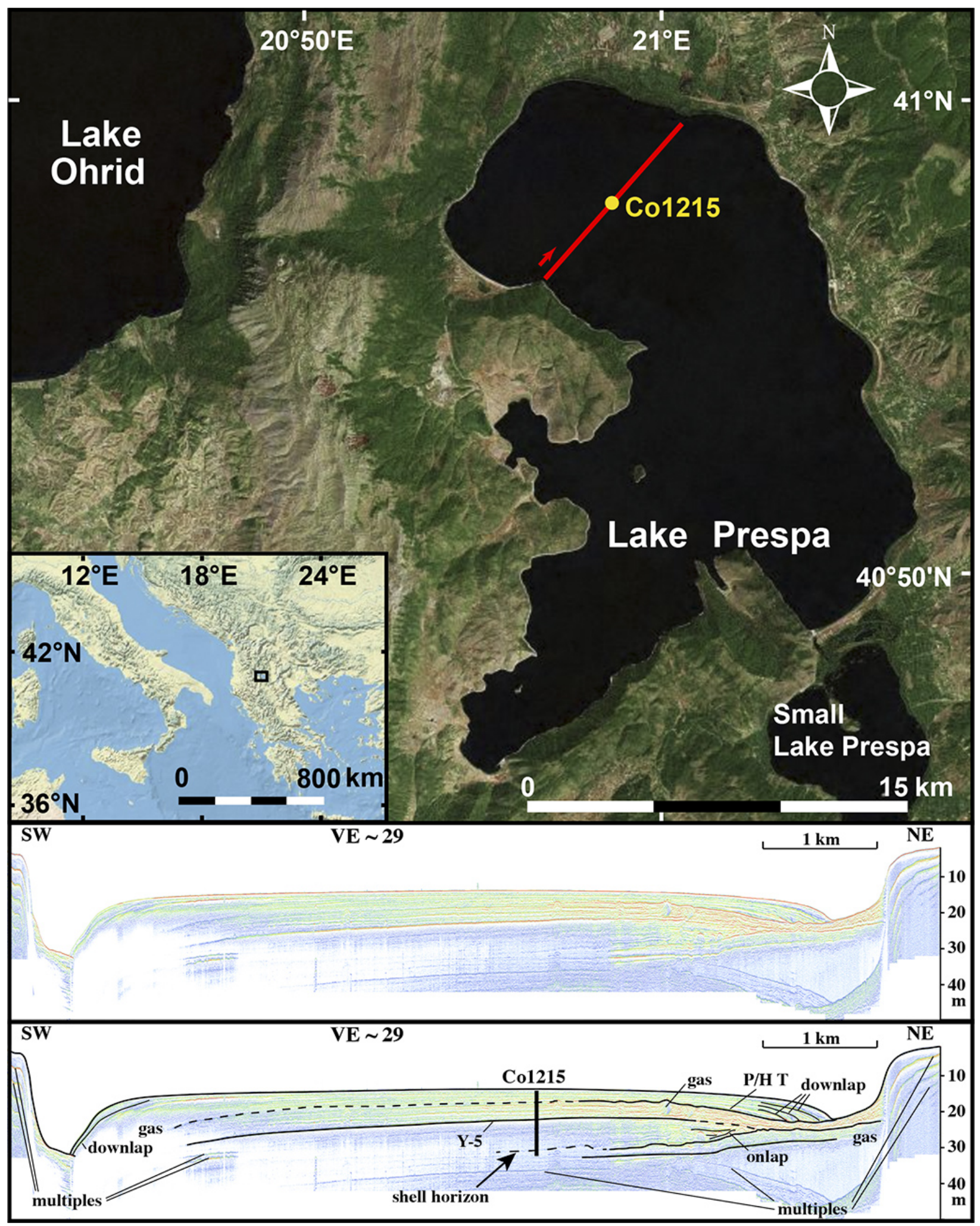

Fig. 1. Map showing the location of Lake Prespa (and Lake Ohrid) in the northeastern Mediterranean region. The red line indicates the hydro-acoustic profile taken in 2007 with an INNOMAR 2000 compact transducer and using the ISE 2.9.2 software. The coring location Co1215 is indicated by a yellow dot. The un-interpreted profile is at the top and the interpreted profile is at the bottom. The depth in the seismic profile is indicated below lake surface and is based on a P-wave velocity of $1450 \mathrm{~m} \mathrm{~s}^{-1}$. The black bar in the seismic profile indicates the location and the recovery depth of sediment core Co1215. The reflectors related to the Y-5 tephra and the Pleistocene/Holocene transition (P/H T) are marked by the black lines (modified from Wagner et al., 2012). 


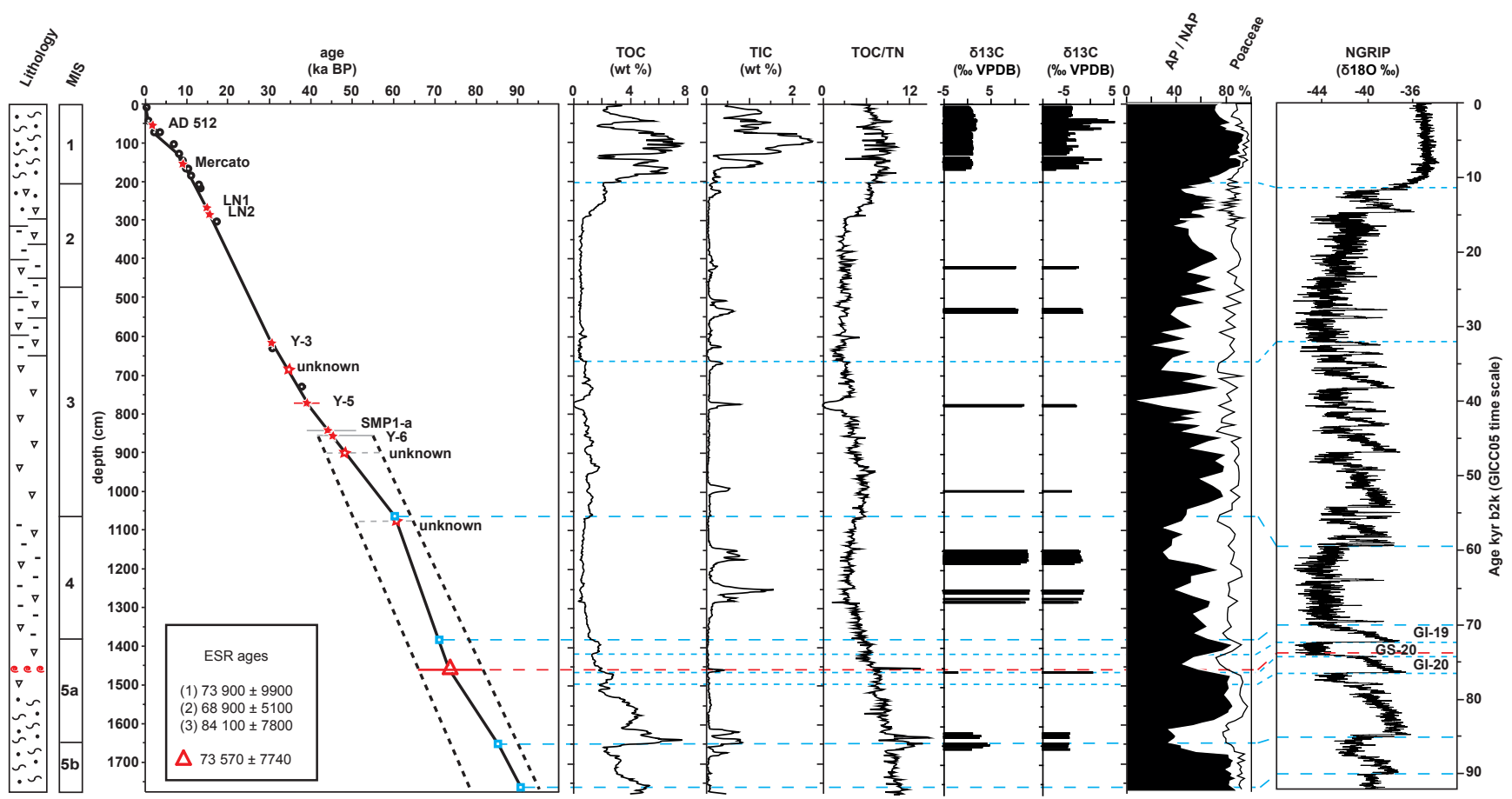

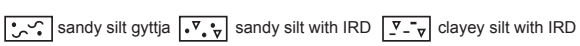

$\nabla \nabla$ silt with IRD Elamination $\quad$ Ee shell layer

Fig. 2. Age model, lithology and selected data sets from core Co1215 from Lake Prespa (data from Damaschke et al., 2013; Wagner et al., 2012; Leng et al., 2013; Panagiotopoulos et al., 2013b). Chronological tie points are indicated by black dots (radiocarbon ages), red stars (tephras; open stars were not used for the age-depth model), and blue squares (cross correlation with NGRIP). The oxygen isotope data set from NGRIP (North Greenland Ice Core Project members, 2004) is based on the Greenland Ice Core Chronology 2005 (GICC05) timescale (GICC05modelext, 2010 and references therein). GICC05 ages are given in units of b2k (years before 2000 AD). Dashed lines indicate tie points of core Co1215 with NGRIP-GICC05, modified after Damaschke et al. (2013).

by a short-term change correlated with a Heinrich event (cf. Wagner et al., 2010), as none are reported around $74 \mathrm{ka}$. Moreover, the more pronounced Heinrich events, which occurred later between MIS 4 and 2 and are characterized by distinct peaks in TIC (siderite), have unusual $\delta^{13} \mathrm{C}$ values related to their mode of formation (Fig. 2) and are not seen in the seismic data. Therefore, the short-term event leading to the distinct lake level lowering in Lake Prespa is apparently unique for the last $92 \mathrm{ka}$.

\section{Interpretation and conclusions}

The sensitivity of Lake Prespa to changes in the hydraulic regime is known from recent observations (e.g. Popovska and Bonacci, 2007) and is likely enhanced by the lake having a relatively large surface area in contrast to a low volume.

Due to the lake level lowering, near-shore habitats of D. presbensis likely became subaerial and eroded, and redistribution of shell fragments into the central parts of the lake would have occurred due to enhanced wave and current activity. Although the lake level was almost certainly lower, the deposition of predominant fine-grained sediments suggests that lacustrine pelagic sedimentation was still occurring at the coring location. A potential recovery from the $74 \mathrm{ka}$ lake level lowstand is probably correlated with an important spatial expansion event of $D$. presbensis from Lake Prespa to neighbouring water bodies. According to independent mitochondrial DNA data, this event took place about $72 \mathrm{ka}$ ago, and the confidence interval for this estimate is very high (95\% CI: 0-153 ka; Wilke et al., 2010).

A major change in the hydraulic regime and a distinct lake level lowering around $74 \mathrm{ka}$ could have been the result of an increased outflow from Lake Prespa. Today, water loss is mainly through evaporation $(52 \%)$ and outflow through karst aquifers $(46 \%)$ into the larger Lake Ohrid located $150 \mathrm{~m}$ below and ca. $10 \mathrm{~km}$ to the west (Fig. 1). A higher outflow from Lake Prespa could be the result of a more active karst aquifer system connecting Lake Prespa and Lake Ohrid due to greater tectonic activity and/or karstic processes. Though tectonic activity in the Balkan region is common (e.g. Reicherter et al., 2011), a significant tectonic event at the end of MIS 5 has not been described thus far. Mass movements, land slides and the formation or reestablishment of older water pathways are common in karstic 
environments and could have increased the outflow of Lake Prespa. However, a second tectonic event and/or a second karstic phenomenon would be required to reduce the outflow following the end of the lake level lowstand.

Alternatively, a reduced inflow could have caused the lowstand of Lake Prespa around $74 \mathrm{ka}$. Today, the annual inflow is $534 \times 10^{6} \mathrm{~m}^{3}$ or about $15 \%$ of the entire volume of the lake (Matzinger et al., 2006a). River runoff from numerous small streams (56\%) and direct precipitation (35\%) form the main proportion of the annual inflow. Precipitation peaks in winter when snowfalls are frequent (Hollis and Stevenson, 1997). We cannot completely exclude that the lake level lowstand in Lake Prespa was due to a period of higher aridity related to cooling at the transition from GI-20 to GS-20. The apparent decoupling between a longer period of colder and dryer conditions, such as indicated in the pollen record between ca. 75 and $71 \mathrm{ka}$, and the short period of lake level lowstand, such as indicated in internal proxies from the lake for a maximum of ca. $250 \mathrm{yr}$, suggest that seasonal affects probably differed from those of today. Precipitation was probably reduced, but not enough to affect the vegetation significantly. Alternately, the lake level lowstand was probably too short-lived to be clearly visible in the pollen data, particularly given the relatively low resolution of the data set. A comparable lake level lowstand subsequently during GS-20 or during other periods when pollen indicate colder and drier conditions, such as during the Heinrich events is not observed (see also Panagiotopoulos et al., 2013b). Other short-lived aridity events are not known to have occurred around $74 \mathrm{ka}$ from the region. However, there is a remarkable correlation between the age of the Lake Prespa lowstand around $74 \mathrm{ka}$ and the Toba eruption at $75.0 \pm 0.9 \mathrm{ka}$ (Mark et al., 2013; see also Svensson et al., 2013). The impact of the Toba eruption on the regional or global climate is still under debate (e.g. Timmreck et al., 2012). The data from Lake Prespa suggest that an impact of the eruption is signalled within the regional climate of the Balkans. If there was a so-called volcanic winter, it could have been correlated with drier conditions in the lake catchment superimposed on the overall cooling trend between GI-20 and GS-20. However, tephra from the Toba eruption, i.e. glass shards of calcalkaline composition, have not so far been found in Lake Prespa (or Lake Ohrid). Moreover, although the 1815 AD eruption of the Tambora volcano in Indonesia has demonstrated the impact of volcanic eruptions from the Equator belt to the climate of the Northern Hemisphere (i.e. being responsible for the world-famous "year without summer"; e.g. Oppenheimer, 2003), the mechanisms for a change in atmospheric circulation patterns and reduced precipitation on the Balkans after the Toba eruption need to be explored. In addition, more evidence from other distal records would be needed to prove the climatic impact of the Toba eruption on the Balkan region.

In comparing the record from Lake Prespa with neighbouring Lake Ohrid, which is today significantly $(25 \%)$ fed by water from Lake Prespa via karst aquifers (Matzinger et al., 2006b), a similar lake level lowering at $74 \mathrm{ka}$ is not obvious (Vogel et al., 2010). However, there are some subtle indications of a lower lake level in Lake Ohrid at the end of MIS 5. In the northern part of Lake Ohrid, seismic data indicate a subaquatic terrace at ca. $30 \mathrm{~m}$ water depth, which likely formed in the final stages of MIS 5 (Lindhorst et al., 2010). Moreover, there is a hiatus in core Co1202 from the northern part of Lake Ohrid (Fig. 1), which was extrapolated to have spanned the period ca. 98-82 ka (Vogel et al., 2010). The age at the top of the hiatus is extrapolated over a large interval and only a slight shift in the sedimentation rate during MIS 4 and MIS 3 could alter the top of the hiatus to around $74 \mathrm{ka}$. If there was less inflow from Lake Prespa at that time, a significant lake level lowering could have caused a mass movement with an erosional base leading to the hiatus in core Co1202. Several other records from the northern Mediterranean region show cold and dry conditions, which are probably related to the GS-20 (e.g. Tzedakis et al., 2004; Brauer et al., 2007), but chronological uncertainties hamper the correlation between the individual records and a potential link to the Toba eruption. Moreover, these records do not indicate the exceptionality as it is expressed in the Prespa record for the period discussed. Karst processes and/or tectonic activity are plausible reasons to explain the lake level lowstand in Lake Prespa. However, the chronological correspondence of the lake level lowstand to the Toba eruption is intriguing and key to contributing to the ongoing discussion related to the possible global impact of the Toba eruption (Williams, 2012b).

Acknowledgements. The project is funded by the German Research Foundation (DFG) within the scope of the CRC 806 ("Our way to Europe") and in the UK by NERC and the British Geological Survey.

Edited by: F. Viehberg

\section{References}

Ambrose, S. H.: Late Pleistocene human population bottlenecks, volcanic winter, and differentiation of modern humans, J. Human Evol., 34, 623-651, 1998.

Aufgebauer, A., Panagiotopoulos, K., Wagner, B., Schäbitz, F., Viehberg, F. A., Vogel, H., Zanchetta, G., Sulpizio, R., Leng, M., and Damaschke, M.: Climate and environmental change in the Balkans over the last $17 \mathrm{ka}$ recorded in sediments from Lake Prespa (Albania/F.Y.R. of Macedonia/Greece), Quatern. Int., 274, 122-135, 2012.

Blinkhorn, J., Parker, A. G., Ditchfield, P., Haslam, M., and Petraglia, M.: Uncovering a landscape buried by the super-eruption of Toba, 74,000 years ago: A multi-proxy environmental reconstruction of landscape heterogeneity in the Jurreru Valley, south India, Quatern. Int., 258, 135-147, 2012. 
Brauer, A., Allen, J. R. M., Mingram, J., Dulski, P., Wulf, S., and Huntley, B.: Evidence for last interglacial chronology and environmental change from Southern Europe, P. Natl. Acad. Sci. USA, 104, 450-455, 2007.

Chesner, C. A.: The Toba Caldera complex, Quatern. Int., 258, 518, 2012.

Damaschke, M., Sulpizio, R., Zanchetta, G., Wagner, B., Böhm, A., Nowaczyk, N., Rethemeyer, J., and Hilgers, A.: Tephrostratigraphic studies on a sediment core from Lake Prespa in the Balkans, Clim. Past, 9, 267-287, doi:10.5194/cp-9-267-2013, 2013.

GICC05modelext, available at: http://www.iceandclimate.nbi.ku. dk/data/ (last access: 28 January 2013), 2010.

Hollis, G. E. and Stevenson, A. C.: The physical basis of the Lake Mikri Prespa systems: geology, climate, hydrology and water quality, Hydrobiologia, 351, 1-19, 1997.

Jones, S. C.: Local- and regional-scale impacts of the $\sim 74 \mathrm{ka}$ Toba supervolcanic eruption on hominin populations and habitats in India, Quatern. Int., 258, 100-118, 2012.

Leng, M. J., Wagner, B., Böhm, A., Panagiotopoulos, K., Vane, C. H., Snelling, A., Haidon, C., Woodley, E., Vogel, H., Zanchetta, G., and Baneschi, I.: Understanding past climatic and hydrological variability in the Mediterranean from Lake Prespa sediment isotope and geochemical record over the Last Glacial cycle, Quaternary Sci. Rev., 66, 123-136, 2013.

Lindhorst, K., Vogel, H., Krastel, S., Wagner, B., Hilgers, A., Zander, A., Schwenk, T., Wessels, M., and Daut, G.: Stratigraphic analysis of lake level fluctuations in Lake Ohrid: an integration of high resolution hydro-acoustic data and sediment cores, Biogeosciences, 7, 3531-3548, doi:10.5194/bg-7-3531-2010, 2010.

Louys, J.: Mammal community structure of Sundanese fossil assemblages from the Late Pleistocene, and a discussion on the ecological effects of the Toba eruption, Quatern. Int., 258, 8087, 2012.

Mark, D. F., Petraglia, M., Smith, V. C., Morgan, L. E., Barfod, D. N., Ellis, B. S., Pearce, N. J., Pal, J. N., and Korisettar, R.: A highprecision ${ }^{40} \mathrm{Ar} /{ }^{39} \mathrm{Ar}$ age for the Young Toba Tuff and dating of ultra-distal tephra: Forcing of Quaternary climate and implications for hominin occupation of India, Quatern. Geochronol., doi:10.1016/j.quageo.2012.12.004, in press, 2013.

Matzinger, A., Jordanoski, M., Veljanoska-Sarafiloska, E., Sturm, M., Müller, B., and Wüest, A.: Is Lake Prespa jeopardizing the ecosystem of ancient Lake Ohrid?, Hydrobiologica, 553, 89-109, 2006a.

Matzinger, A., Spirkovski, Z., Patceva, S., and Wüest, A.: Sensitivity of ancient Lake Ohrid to local anthropogenic impacts and global warming, J. Great Lakes Res., 32, 158-179, 2006b.

North Greenland Ice Core Project members: High-resolution record of Northern Hemisphere climate extending into the last interglacial period, Nature, 431, 147-151, 2004.

Oppenheimer, C.: Climatic, environmental and human consequences of the largest known eruption: Tambora volcano (Indonesia) 1815, Prog. Phys. Geogr., 27, 230-259, 2003.

Oppenheimer, S.: A single southern exit of modern humans from Africa: Before or after Toba?, Quatern. Int., 258, 88-99, 2012.

Panagiotopoulos, K., Aufgebauer, A., Schäbitz, F., and Wagner, B.: Vegetation and climate history of the Lake Prespa region since the Lateglacial, Quatern. Int., 293, 157-169, 2013a.
Panagiotopoulos, K., Böhm, A., Leng, M. J., Wagner, B., and Schäbitz, F.: Climate variability since MIS 5 in SW Balkans inferred from multiproxy analysis of Lake Prespa sediments, Clim. Past Discuss., 9, 1321-1362, doi:10.5194/cpd-9-13212013, 2013b.

Petraglia, M. D., Ditchfield, P., Jones, S., Korisettar, R., and Pal, J. N.: The Toba volcanic super-eruption, environmental change, and hominin occupation history in India over the last 140,000 years, Quatern. Int., 258, 119-134, 2012.

Popovska, C. and Bonacci, O.: Basic data on the hydrology of Lakes Ohrid and Prespa, Hydrol. Process., 21, 658-664, 2007.

Reicherter, K., Hoffmann, N., Lindhorst, K., Krastel, S., FernandezSteeger, T., Grützner, C., and Wiatr, T.: Active Basins and Neotectonics: Morphotectonics of the Lake Ohrid Basin (FYROM and Albania), Z. Dtsch. Ges. Geowiss., 162, 217-234, 2011.

Robock, A., Ammann, C. M., Oman, L., Shindell, D., Levis, S., and Stenchikov, G.: Did the Toba volcanic eruption of $\sim 74$ ka B.P. produce widespread glaciation?, J. Geophys. Res., 114, D10107, doi:10.1029/2008JD011652, 2009.

Storey, M., Roberts, R. G., and Saidin, M.: An astronomically calibrated ${ }^{40} \mathrm{Ar} /{ }^{39} \mathrm{Ar}$ age for the Toba super-eruption and global synchronisation of late Quaternary records, P. Natl. Acad. Sci. USA, 109, 18684-18688, 2012.

Svensson, A., Bigler, M., Blunier, T., Clausen, H. B., Dahl-Jensen, D., Fischer, H., Fujita, S., Goto-Azuma, K., Johnsen, S. J., Kawamura, K., Kipfstuhl, S., Kohno, M., Parrenin, F., Popp, T., Rasmussen, S. O., Schwander, J., Seierstad, I., Severi, M., Steffensen, J. P., Udisti, R., Uemura, R., Vallelonga, P., Vinther, B. M., Wegner, A., Wilhelms, F., and Winstrup, M.: Direct linking of Greenland and Antarctic ice cores at the Toba eruption (74 ka BP), Clim. Past, 9, 749-766, doi:10.5194/cp-9-749-2013, 2013.

Timmreck C., Graf, H. F., Zanchettin, D., Hagemann, S., Kleinen, T., and Krüger, K.: Climate response to the Toba super-eruption: Regional changes, Quatern. Int., 258, 30-44, 2012.

Tzedakis, P. C., Frogley, M. R., Lawson, I. T., Preece, R. C., Cacho, I., and de Abreu, L.: Ecological thresholds and patterns of millennial-scale climate variability: The response of vegetation in Greece during the last glacial period, Geology, 32, 109-112, 2004.

Vogel, H., Wagner, B., Zanchetta, G., Sulpizio, R., and Rosén, P.: A paleoclimate record with tephrochronological age control for the last glacial-interglacial cycle from Lake Ohrid, Albania and Macedonia, J. Paleolimnol., 44, 295-310, 2010.

Wagner, B., Vogel, H., Zanchetta, G., and Sulpizio, R.: Environmental change within the Balkan region during the past ca. $50 \mathrm{ka}$ recorded in the sediments from lakes Prespa and Ohrid, Biogeosciences, 7, 318-3198, doi:10.5194/bg-7-3187-2010, 2010.

Wagner, B., Aufgebauer, A., Vogel, H., Zanchetta, G., Sulpizio, R., and Damaschke, M.: Late Pleistocene and Holocene contourite drift in Lake Prespa (Albania/F.Y.R. of Macedonia/Greece), Quatern. Int., 274, 112-121, 2012.

Wilke, T., Schultheiß, R., Albrecht, C., Bornmann, N., Trajanovski, S., and Kevrekidis, T.: Native Dreissena freshwater mussels in the Balkans: in and out of ancient lakes, Biogeosciences, 7, 3051-3065, doi:10.5194/bg-7-3051-2010, 2010. 
Williams, M.: The similar to $73 \mathrm{kyr}$ Toba super-eruption and its impact: history of a debate, Quatern. Int., 258, 19-29, 2012a.

Williams, M.: Did the 73 ka Toba super-eruption have an enduring effect? Insights from genetics, prehistoric archaeology, pollen analysis, stable isotope geochemistry, geomorphology, ice cores, and climate models, Quatern. Int., 269, 87-93, 2012b.

Wolff, E. W., Chappellaz, J., Blunier, T., Rasmussen, S. O., and Svensson, A.: Millennial-scale variability during the last glacial: The ice core record, Quaternary Sci. Rev., 29, 2828-2838, 2010. 